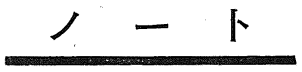

\title{
油脂酸化防止剂の酢酸ビニルおよび アマニ油の重合に及ぼす影響
}

\author{
尾 藤 忠 旦* ・加藤 寿*
}

Effect of Antioxidants for Polymerization of Vinyl

Acetate and Linseed Oil.

Tada, aki Bıтö and Hisashi KATō

\section{I. 緒 言}

油脂酸化防止剤が，酸化の及ならず重合飞対しても抑

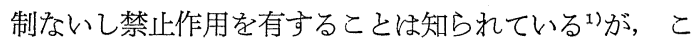
れらの研究は招るにスチレンに関するるので, 酶酸ビニ

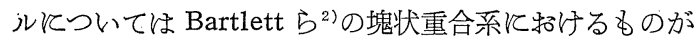
見られる程度である。筆者らは, 酸化防止剤の油脂重合 そ及に゙す様子を見る前に，模型実験として一層重合しゃ すい䣷酸ビニルの溶液重合汶対する態度を調べ，その後 そアマニ油について研究を行った。酸化防止剤について はビニル重合抑制剤または禁止剤として今までとあまり 研究されていないるのを選んだ。

\section{II. 実 験 方 法}

酶酸ビニル (bp $\left.73^{\circ} \mathrm{C}\right)$ は日本合成化学製品で, 井上, 桜田ら ${ }^{3)}$ の方法飞準じて，使用数日前飞無水炭酸カリウ 么を加光使用直前々苲留し， $72.5 \sim 72.9^{\circ} \mathrm{C}$ の留分を用 いた。また，均一系で重合させる必要上，溶媒として酢 酸エチル (bp $\left.77.1^{\circ} \mathrm{C}\right)$ を蒸留して使用した。重合には 冷却管を付した硬質ガラス試験管（径 $1.8 \mathrm{~cm}$, 深さ 18.5 $\mathrm{cm})$ を用い, 恒温ソウ (精度 $0.5^{\circ} \mathrm{C}$ ) 中静置した。試 料は各実験を通じて $8 \mathrm{~m} l$ を用いた。重合測定は, 井 本，坦内ら ${ }^{4)}$ の方法飞準じて行った。すなわち，一定時 間後飞重合容器を取り出して直ちと冷却し重合進行を停 止し, 試料中より $7 \mathrm{~m} l$ をオストワルド型粘度計飞入れ $30 \pm 0.1^{\circ} \mathrm{C}$ の恒温りウ中で流下時間を測定し, $P=T / T^{\prime}$ (sec) ( $T^{\prime}$ は反応時間 0 のときの流下時間, $T$ は一定 時間反応後の流下時間）より重合度を求めた。

第一飞防止剤の濃度の影響を調べ，つぎと重合開始剤 過酸化ベンゾイルを添加， $70^{\circ} \mathrm{C}$ と和ける防止剤の重合 に対する態度を見, 最後にアマニ油 (酸価 0.8 , ケン化

* 名古屋工業大学工業化学科 (名古屋市昭和区)

Nagoya Institute of Technology
価 190.6，ヨウ素価 174.2）の重合の場合につき実験を 行った。

\section{III. 実験結果亡考察}

酢酸ビニル $(90.2 \%)$ 飞, 溶媒として酷酸エチルを用 い $72^{\circ} \mathrm{C}$ で重合系に及ぼす各種酸化防止剤の濃度の影響 を調べた結果は表-1のと招りである。

この結果を見ると，酸化防止剤を含ま係は他のどの $P$ よりも大であり，一般と重合防止能が認められるが， サリチル酸メチルとバニリンは作用が弱い。殊にバニリ ンは図-1の上うに添加量の增加とともに $P$ も増加してい る。このととから，バニリンの重合抑制能は微弱であ

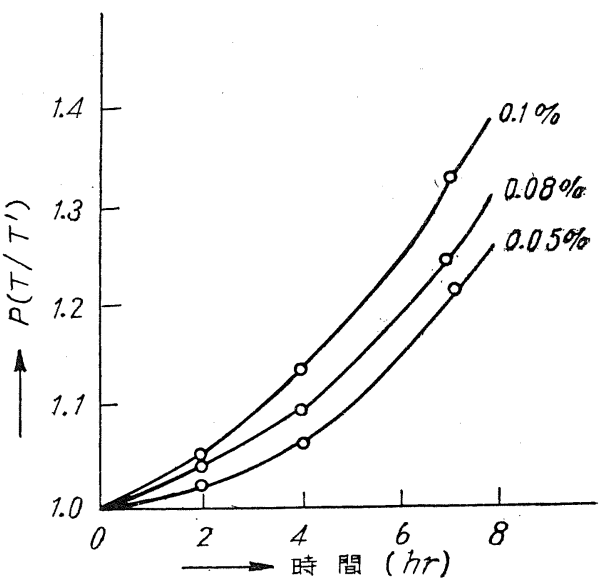

図-1

り,ささらと活性化された䣷酸ビニルとバニリンと結合し て生ずる遊離基はわずかながら重合開始作用があると思 われる。中村の酸化防止の研究(5でもバニリンのよろな 芳香族アルデヒドには酸化促進能があると述べられてい る。以上の 2 種以外は $0.05 \%$ で有効であり,なかでる アミン類, ナフトール類怙よびプロピルガレートがすぐ 
表-1（**は無添加の場合を0.05\%欄に記した）

\begin{tabular}{|c|c|c|c|c|c|c|c|}
\hline \multirow{2}{*}{\multicolumn{2}{|c|}{$\frac{\underbrace{}_{\text {添加量 }(\%)}}{\left.\text { 防止剂 } \begin{array}{l}\text { 間 } \\
(\mathrm{hr})\end{array}\right)}$}} & \multicolumn{2}{|c|}{0.05} & \multicolumn{2}{|c|}{0.08} & \multicolumn{2}{|c|}{0.10} \\
\hline & & $\mathrm{T}$ & $\mathrm{P}$ & $\mathrm{T}$ & $\mathrm{P}$ & $\mathrm{T}$ & $\mathrm{P}$ \\
\hline \multirow{4}{*}{ —— } & 0 & 25.08 & 1.00 & & & & \\
\hline & 2 & 27.09 & 1.08 & & & & \\
\hline & 4 & 31.10 & 1.24 & & & & \\
\hline & 7 & 34.28 & 1.37 & & & & \\
\hline \multirow{3}{*}{ 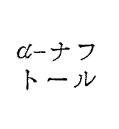 } & 2 & 24.85 & 0.99 & 24.86 & 0.99 & 25.35 & 1.01 \\
\hline & 4 & 25.12 & 1.00 & 24.88 & 0.99 & 25.80 & 1.03 \\
\hline & 7 & 25.34 & 1.01 & 25.32 & 1.01 & 26.08 & 1.04 \\
\hline \multirow{3}{*}{$\begin{array}{l}\beta \text {-ナフ } \\
ト ー ル ~\end{array}$} & 2 & 25.10 & 1.00 & 25.33 & 1.01 & 25.30 & 1.01 \\
\hline & 4 & 25.32 & 1.01 & 25.35 & 1.01 & 25.34 & 1.01 \\
\hline & 7 & 25.33 & 1.01 & 25.33 & 1.01 & 25.60 & 1.02 \\
\hline \multirow{3}{*}{ 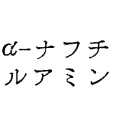 } & 2 & 25.33 & 1.01 & 24.83 & 0.99 & 24.86 & 0.99 \\
\hline & 4 & 25.82 & 1.03 & 25.35 & 1.01 & 25.30 & 1.01 \\
\hline & 7 & 26.34 & 1.05 & 26.32 & 1.05 & 25.32 & 1.01 \\
\hline \multirow{3}{*}{$\begin{array}{l}\beta \text { ーナフチ } \\
\text { ルアミン }\end{array}$} & 2 & 25.36 & 1.01 & 25.34 & 1.01 & 25.36 & 1.01 \\
\hline & 4 & 25.56 & 1.02 & 25.33 & 1.01 & 25.34 & 1.01 \\
\hline & 7 & 26.08 & 1.04 & 25.37 & 1.01 & 25.61 & 1.02 \\
\hline \multirow{3}{*}{$\begin{array}{l}\text { プロピル } \\
\text { ガレート }\end{array}$} & 2 & 25.34 & 1.01 & 25.35 & 1.01 & 25.30 & 1.01 \\
\hline & 4 & 25.34 & 1.01 & 25.33 & 1.01 & 25.34 & 1.01 \\
\hline & 7 & 25.36 & 1.01 & 26.11 & 1.04 & 26.06 & 1.04 \\
\hline \multirow{3}{*}{$\begin{array}{l}\text { エチルプ } \\
\text { ロトカテ } \\
\text { キュエー } \\
\text { ト }\end{array}$} & 2 & 25.11 & 1.00 & 25.33 & 1.01 & 25.36 & 1.01 \\
\hline & 4 & 25.34 & 1.01 & 25.36 & 1.01 & 25.61 & 1.02 \\
\hline & 7 & 25.58 & 1.02 & 25.88 & 1.03 & 26.12 & 1.04 \\
\hline \multirow{3}{*}{$\begin{array}{l}\text { アルドー } \\
\text { ルー } \\
\text { フチルナ } \\
\text { ミン }\end{array}$} & 2 & 24.81 & 0.99 & 24.83 & 0.99 & 24.85 & 0.99 \\
\hline & 4 & 25.35 & 1.01 & 25.10 & 1.00 & 25.09 & 1.00 \\
\hline & 7 & 25.83 & 1.03 & 25.56 & 1.02 & 25.33 & 1.01 \\
\hline \multirow{3}{*}{$\begin{array}{l}\text { サリチル } \\
\text { 酸メチル }\end{array}$} & 2 & 25.58 & 1.02 & 25.36 & 1.01 & 25.33 & 1.01 \\
\hline & 4 & 26.84 & 1.07 & 26.33 & 1.05 & 25.60 & 1.02 \\
\hline & 7 & 26.84 & 1.07 & 26.59 & 1.06 & 25.87 & 1.03 \\
\hline \multirow{3}{*}{$\begin{array}{l}p-ア ミ ノ \\
\text { アセトフ } \\
\text { エノン }\end{array}$} & 2 & 25.58 & 1.02 & 25.59 & 1.02 & 26.55 & 1.06 \\
\hline & 4 & 25.85 & 1.03 & 26.07 & 1.04 & 26.88 & 1.07 \\
\hline & 7 & 26.06 & 1.04 & 26.32 & 1.05 & 26.88 & 1.07 \\
\hline \multirow{3}{*}{ バニリン } & 2 & 25.55 & 1.02 & 26.08 & 1.04 & 26.35 & 1.05 \\
\hline & 4 & 26.58 & 1.06 & 27.59 & 1.10 & 28.59 & 1.14 \\
\hline & 7 & 30.85 & 1.23 & 31.35 & 1.25 & 33.61 & 1.34 \\
\hline
\end{tabular}

れている。

過酸化ベンゾイルの $0.1 \%$ を含む酢酸ビニル $(50.1 \%)$ の重合に及ぼす防止剤の作用を，溶媒酢酸エチル，温度 $70^{\circ} \mathrm{C}$, 防止剤 $0.05 \%$ で実験した結果は図-2のと招りで ある。

図のうち，A\&無効，Bは弱い抑制剂，C，D忹重合 抑制剤，Eは強い抑制剤，F，Gは重合禁止剤とだいた

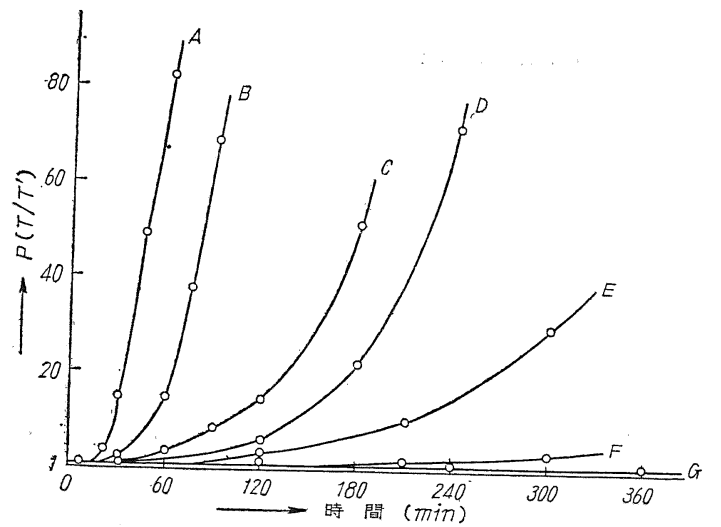
$\mathrm{A}:\left\{\begin{array}{l}\text { 無添加 } \\ \text { サリチル酸メチル }\end{array}\right.$

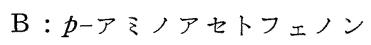 C : $\beta$ ーナフトール D : エチルプロトカテキュエート

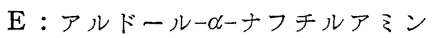

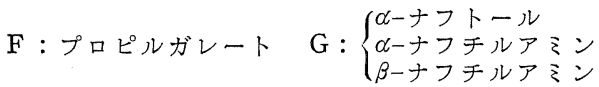

図-2

い考党られる。 $\alpha$-ナフトールが $\beta$-ナフトールより強力 なととは油脂の酸化防止飞る認められ6), 実験範囲では ナフタリン核を有するものが効力が強く, また, フェノ ール類よりもアミン類の方が有効であるが，これは油脂 酸化防止の場合とは逆である。フェノール類では水酸基 の数が増すとつれて効力も大となつている。アミン類で はアルドールーローナフチルアミンのような第三級アミン は第一級アミンよりも作用が弱い。

つぎに, アマニ油 $10 \mathrm{~g}$ 亿防止剂 $0.05 \%$ 添加して油 浴上で $200 \pm 2{ }^{\circ} \mathrm{C}$ 飞加熱し, 一定時間後に取り出して冷 却し $25 \pm 0.1^{\circ} \mathrm{C}$ の恒温りウで粘度計を用い重合度を求 めた結果は図-3のと招りで, 酶酸ビニル飞比し重合度が 小さいため防止剤の効果は著しくはないがそれでる有効 なととはわかり, 殊に興味のある点は, 油では酸化防止 の場合と同じフェノール系がアミン系よりも効力が大き

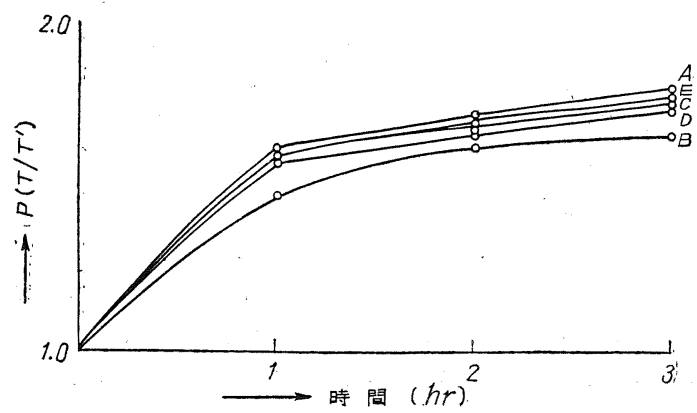

$\mathrm{A}$ ：無添加 B：プロピルガレート C : ブチルヒドロキ シアニソール $\mathrm{D}: \alpha$-ナフチルアミン $\mathrm{E}:$ アルドール-ナフチルアミン

図-3 
い傾向があることでめる。油脂の酸化が進めげ当然重合

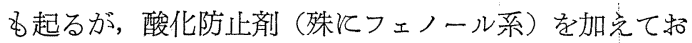
けば酸化，重合とるに防止できて好都合であることがわ かった。

\section{IV. 総 括}

$\alpha$-ナフトール, $\alpha$-ナフチルアミン, $\beta$-ナフチルアミン プロピルガレートは酢酸ビニルに対し重合禁止作用があ り, アルドールー $\alpha$-ナテルアミンは強い抑制作用, エ チルプロトカテキュエート， $\beta$ ーナフトールは普通の抑制 作用， サルチル酸メチル，バニリンは無効または弱い重合開始 作用がある。アマニ油の重合に対しては, 酢酸ビニルの 場合のようと顕著ではないがプロピルガレート，
チルアミン，ブチルヒドロキシアニソールその他に抑制 作用が見られた。

終りに，本実験の御指導を賜わった外山修之教授飞厚 く感謝の意を表する。 (昭和 33 年 3 月 5 日受理)

$$
\text { 文献 }
$$

1) S.G. Foord, J. Chem. Soc., 143. 48 (1940); G. V. Schulz, Chem. Ber., 80, 232 (1947); 坦内, 高分子展望, 12, 74 (1955)

2) P.D. Bartlett, H. Kwart, J. Am. Chem. Soc., 72, 1051 (1950)

3) 井上, 桜田, 高分子化学, 7, 211 (1950)

4) 井本, 晅内, 高分子化学, 5, 117 (1948)

5) 中村, 工化, 36, 749 (1933)

6) 小森, 榊原, 有合化, 13, 164 (1955)

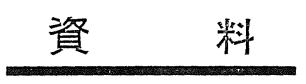

\title{
液 相 熱 拡 散分別分離
}

\author{
浅 原 照 三* ・関口英 人*
}

\section{Liquid Thermal Diffusion Fractionation}

\author{
Teruzō AsAhara and Hideto SekiguchI
}

熱搪散分離法は物質の分離，精製扔よび分析飞新しい 手段として登場し，広く利用されている。熱拡散現象乞 のものは 1856 年 C. Ludwig とよって発見され, Ludwig-Soret 効果 ${ }^{1)}$ とて古くから知られていたが， 1938 年 Clusius, Dickel ${ }^{2)}$ とょって気相で塩素の同位元素を 分離できるという報告が出るまでは，長い間実用的な応 用に関する研究は行われなかった。Clusius, Dickel は 装置の面で, はじめて熱拡散法を多段式分離法とし, 容 量と分離効率を著しく増すことに大きな貢献をし，ガス 状無機物をとの構成分子の質量の違いによって分離する ことに多くの応用を見出した。その後間もなく有機液体 飞研究の対象が向けられたが, それまでの無機物に関す るデータとは分離の向きが全く逆に，そのう方無機物よ りはるかと效率上く有機物の分離が行われることがわか って非常に興味が持たれ始め, ここ十数年の間急注 究が活発に行われるようになった。一方熱拡散に関する 理論的な説明も，有機液体を手がけるようとなってから は多くの複雑な現象が見つけられて, 從来, 分子の質量 の差によって分離されると考光られていた簡単な理論で は説明できなくなり, 液体論の立場から興味ある研究対

* 東京大学生産技術研究所 (千葉市弥生町 1 )
象となっている。しかし，現在な招，どしな場合にも適 用できる一般法則は未だわからないまま，実用面では 蒸留などの他の方法では分離不可能な混合物質を, 各成 分飞分離することが，多方面飞開拓されてきた。容量が 小さく, 熱効率が悪いなぞの欠点はあるが, 非常に簡単 な装置で石油招よび油脂飞関する工業的飞る有用な分離 が可能であるので, 特にこれらの分野の研究についてそ の情勢を概観してみよう。

\section{I. 原理および理論的説明}

\section{1. 原 理}

せるい間げき（隙）を隔てて鉛直方向に平行に相対し た二枚の壁の一方を加熱し，他方を冷却してその間㴔 激な温度勾配をつくって，そこに二成分系混合流体を入 れてやると，各成分によってそれぞれ異なる拡散による 物質移動が起り，熱壁付近の流体と冷壁付近のそれとの 間には, 各成分についての濃度差が生じる。この現象 を，発見者の名にちなんで Ludwig-Soret 効果（または 単に Soret 効果), あるいは熱搪散と呼んでいる。

熱拡散の量怯, 濃度 $C$ と $X$ 方向の温度勾配 $\partial T / \partial X$ 飞比例する。すなわち（1）式で表わされる。ここで $D^{\prime}$ 